\title{
Waste Identification and Elimination Using Lean Methods in Receiving Process: A Case Study at PT IPC Container Terminal
}

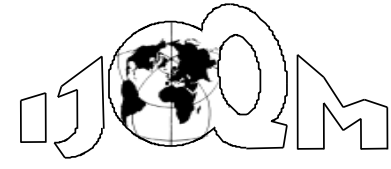

DOI: $10.46970 / 2020.26 .3 .2$

Volume 26, Number 3

September 2020, pp. 183- 193
Mohammad Ichsan

Bestari Nur Arasy

Mohamad Fadly

Muhamad Rizki Nafi Adhani

Management Department, BINUS Business School

Undergraduate Program,

Bina Nusantara University, Jakarta, Indonesia 11480

(d3919@binus.ac.id)

Lean is a management philosophy and methodology used to improve quality and reduce waste. This paper aims to identify and eliminate waste using lean methods at PT IPC Container Terminal. Tanjung Priok Port. Current Value Stream Mapping (VSM) of receiving process was developed to shows all processes and activities, It is identified there are 6 processes with total of 37 activities in receiving process of Tanjung Priok Port. Based on the results of Value Stream Mapping (VSM), a questionnaire of Value-Added Assessment (VAA) is developed to classify activities into Value Added (VA), Non-Value Added (NVA), or Necessary Non-Value Added (NNVA). Then the results of VAA was analyzed using 7 waste of analysis. The results of this paper show that it is identified there are 9 activities of Non-value Added, and 3 activities of Necessary Non-Value Added (NNVA).

Keywords: Lean Methods, Value Stream Mapping (VSM), Value Added Assessment (VAA), 7 Waste Analysis

\section{Introduction}

Indonesia is one of the biggest archipelagic countries in the world where two-thirds of its territory is water which makes Indonesia depends heavily on maritime transportation for domestic and international trade. One of the main focuses of Government of Republic Indonesia is to improve the performance of the seaports. Currently ports around the world are faced with many changes in global trade. The sea ports have become one of the facilities to support the mobility of goods for land transport and sea transport mode. The presence of satisfactory port is needed and to be able to have ports with efficient and sustainable operations, Indonesia needs to have a better operational system that will give an add-value.

PT IPC Container Terminal (TPK) which is the object of this research was established as an effort of the founder and parent entity, PT Pelabuhan Indonesia II (Persero) or Pelindo II or known as Indonesia Port Company (IPC). The main responsibilities of IPC TPK are to provide good services to its customers by providing container services with network system that is integrated between ports and managed professionally. IPC TPK's container terminal services are supported by modern and reliable services and facilities as well as professional human resources 
that uphold the Company's code of conduct, so that expected to be able to meet the stakeholder's expectations which ultimately can support the flow of Indonesia's trade growth. Until now, PT IPC Container Terminal is managing container terminal in six ports spread in western and central Indonesia, namely Pontianak Port, West Kalimantan; Panjang Port, Lampung; Palembang Port, Palembang; Teluk Bayur Port, Padang; Jambi Port; and Tanjung Priok Port, Jakarta. Tanjung Priok Port is the largest and busiest port in Indonesia. This port handles more that 30\% of Indonesia's non-oil and gas commodities, while 50\% of all goods flowing in/out of Indonesia are passing through this port. Therefore, Tanjung Priok Port is a barometer of the Indonesian economy. (PT IPC Terminal Petikemas, 2018)

Container terminal is a link between different transport modes in the global logistics chain; therefore, container terminal is a very important to the efficiency of the whole chain. The container is an alternative widely used to distribute goods from the land transport to sea transport mode. One of the activities in container terminal is the receiving process. The receiving process starts from open stack submission, Payment, printing receiving card, Container Mapping Ship (CMS), and open stack activities which includes gates in inspection, weighting, and stacking receiving and gate out inspection.

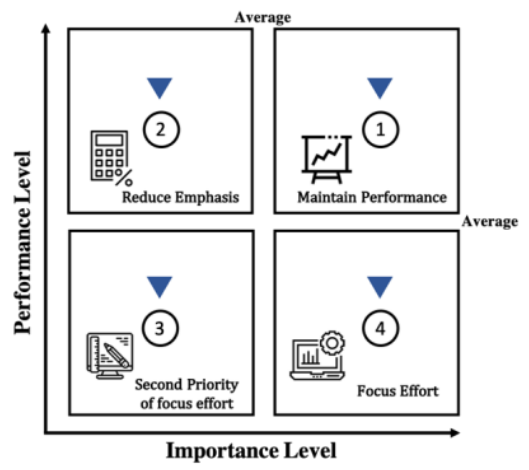

Figure 1 Importance - Performance Analysis Matrix in PT IPC Container Terminal KPI 2019

Figure 1 shows that quadrant 4 is the focus effort / priority improvement. Based on PT IPC Container Terminal Key Performance Indicators (KPI) 2019, services that needs improvement or in quadrant 4 are:

1. The availability of tools to facilitate stacking activities

2. Physical condition and access of the road in port area are not in a good condition

3. Yard operational equipment are adequate

4. Billing center is adequate

5. Invoice submitted are convenient

Other activities also identified in receiving process are waiting trucks on in receiving gate that leads to queues. Such condition has no add-value and it is considered as wastes. It will affect service quality. According to Heizer et al. (Heizer et al., 2017), waste is any activity that does not add value in the eyes of the customer. It was identified that some of non-value-added activities are found in receiving process which has to be eliminated. The lean operations method can be used to 
eliminates waste through continuous improvement and focus on exactly what the customer wants. Identified waste based on lean operation can be categorized as over production, queues, transportation, inventory, over processing, motion and defective products (Heizer et al., 2017).

This study aims to identify and eliminate wastes in receiving process that expected helps the company to improve service quality in receiving process of PT IPC Container Terminal of Tanjung Priok port using lean operation method.

\section{Methodology}

This research was conducted to determine the process to identify waste at each stage of the process. This research is a qualitative research and case study that will be using combination of desktop study, observation, and questionnaire. This research requires primary and secondary data that are collected from desktop study, observation, and questionnaire.

The first step in this study is using Value Stream Mapping (VSM), which is a structured diagram used in mapping the process and information flow of an operational activity from the beginning to end. The purpose of Value Stream Mapping (VSM) is to obtain the details of process stages and times, so that the activities can be classified as Value Added and Non-Value-Added activities. This analysis using Value Stream Mapping will also shows the cycle time and lead time of receiving activity. In this case, current value stream mapping was illustrated to show the current situation of the company's business process. Proposed Value Stream Mapping will also be illustrated as the results of this research.

In the second stage of this research, a questionnaire of Value-Added Assessment is developed and will be sent to IPC Container Terminal staff who are directly involved in the receiving activities business processes. The questionnaire is used to determine the types of activities in receiving process to be classified as Value Added (VA), Non-Value Added (NVA), Necessary Non-Value Added (NNVA).

The last stage of this research is using only the Non-value added (NVA) and Necessary Non-Value Added (NNVA) activities that was obtained from Value Added Assessment (VAA) results to be categorized into 7 Waste category analysis. The proposed improvements are then developed to overcome the wastes occurred in the receiving process of the container terminal.

\section{Systematic Literature Review on Lean Management}

To overcome this problem, it is necessary to understand the material from theoretical aspects. Lean is a management philosophy and methodology, utilizing various tools and techniques, which aim to improve quality and reduce waste (Waterman \& McCue, 2012). Lean is one methodology that used to make improvement (Gupta \& Sharma, 2018). Olesen et al (2015) stated, Lean is a philosophical approach consisting of a set of principles that encourage organizations to continue to add value to the company's operations. Minh et al. (2018) argued that lean is one of the systematic approaches to achieve higher value for organization through eliminate non-value-added activities. Based on Heizer et al. (2017), Lean Operations supply the customer with exactly what the customer wants when the customer wants it, without waste, through continuous improvement. Meanwhile, according to Sharma 
et al. (2018) Lean is simply a systematic technique or approach to identify and eliminating the waste through the continuous improvement by flowing the product at the pull of the customer in pursuit of the perfections. The main aim is to eliminate the wastages in every area of the production including the customer relations and the product design and suppliers.

Originally, Lean was initiated in manufacturing industry (Womack et al., 1990). Froon (2010) mentioned that lean was actually not only for manufacturing industry. Although the initial concept was introduced from Toyota Production System (TPS), but in its development, this concept could be applied in the service industry. Studies by Nagapan et al. (2012) and (2018), shows that not only in manufacturing industry but lean has been accepted and adopted in all fields. A study by Andrés-López et al. (2015) ensuring lean methodologies applicability to service environment. Sanker(2020) stated that just like lean manufacturing ideas, lean service also focuses on eliminating waste and increasing efficiency in the work process, identify and eliminate unnecessary process steps (non-value) and activities are built and improved from time to time and continuously. Radnor et al (2006) in its study assessed the application of lean in public sector in order to evaluate its impact on productivity and quality of service. Vignesh et al. (2016) also reveals that lean can be successfully implemented in service sector to remove non-value added activities.

A toolkit of methods for practical use at the operational level has been developed to support Lean. Value stream mapping is one of the tools which used to analyses the flow activities to highlight area that do not add value from customer's perspective (Radnor et al., 2006). VSM was popularized by Rother and Shook in Seth and Gupta (2005). Value Stream Mapping (VSM) is all the actions (both value added and nonvalue added) currently required to bring a product through the main flow essential to every product (Rother \& Shook, 1999). Seth et al (2008) stated that Value Stream Mapping (VSM) can be done in the same way for practically any business activity and expanded upstream or downstream. A study by Morlock and Meier (2015) represents adaption of the Value Stream Mapping for services industry to give an overview of processes and show process improvements using VSM tool. Study by Torres \& Gati (2009) also indicates that Value Stream Mapping is a tool used to showing mapping for material flow and find operational inefficiencies in a process. According to Gupta et al (2016) lean tool Value Stream Mapping can identify and eliminate root cause leading to improve service quality and customer experience, in a rapid way. Daruka et al. (2017) in his study stated that Value Steam Mapping is the solution to identifies the source of waste and to scale down them analytically. Hines and Rich (1997) stated that the main focus of Value Stream Mapping includes waste removal, the complete value adding and non-value adding process, from conception of requirement back through to raw material source and back again to the consumer's receipt of product. Seth and Gupta (2005) also stated in their study that Value Stream Mapping tool could improve overall flow to the customer with little or no waste. Amrina et al. (2019) stated that the purpose of VSM is to obtain the description of process stages and process times, so that it can be seen the activities classified as Value Added and Non-Value Added. Then developed a questionnaire of ValueAdded Assessment (VAA) to determine the types of activities; Value added (VA), Non-value Added (NVA), or Necessary bur Non-Value Added (NNVA). 
Lean operations set their sights on perfection: only value-added activities, and no waste (Heizer et al., 2017). The rationale behind Lean is on waste removal both inside and between company (Hines \& Taylor, 2000). Waste Removal is one of the Important aspects in Lean in which should be focused in Service (Asnan et al., 2015). Waste is any activities that has non-value added (Santosa \& Sugarindra, 2018). According to Heizer et al. (2017) Waste is any activity that does not add value in the eyes of customer. Taiichi Ohno (1988), noted for his work on Toyota Production System, identified seven categories of waste: Overproduction, Queues, Transportation, Inventory, Motion, Over processing, Defective Product.

Based on literature review, Lean operation will be the solution to this research. It is believed that by applying lean tools; Value Stream Mapping, Value Added Assessment, and identified waste into seven categories of waste, IPC Container Terminal Receiving process will be more effective and customer be satisfied.

\section{The Proposed Theoretical Framework}

The current state mapping is drawn from standard operating procedure (SOP). The current Value Stream Mapping shows all processes and activities through all of the receiving process of terminal container port of Tanjung Priok. The process starts from Open stack requests by customer until gate out process.

The process of stacking container is the longest cycle time of 11 minutes. It is because lack of the availability of tools to facilitate stacking activities and Yard operational equipment aren't adequate. While the fastest cycle time is the process of customer getting receiving card. Then the total of cycle is 23:31 minutes. Besides the cycle time it is found that the total of lead time is 02:24:07 minutes.

The process flow map Current State Value Stream Mapping illustrated as follows

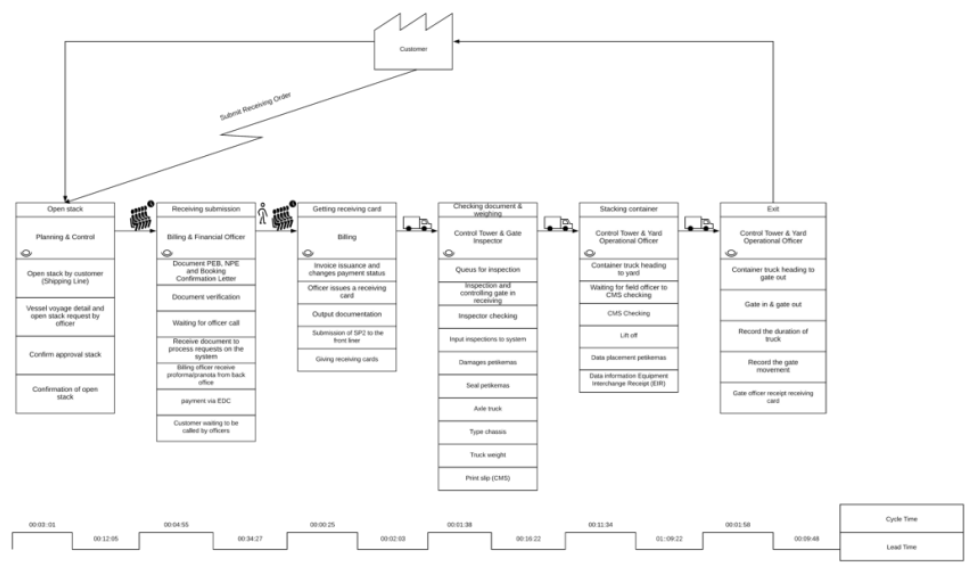

Figure 2 Current Value Stream Mapping

It can be seen that there is a large gap between cycle time and lead time, which can be assumed that there is still a waste of this receiving process. After current state value stream mapping is illustrated, a questionnaire of Value-Added Assessment (VAA) is developed and distributed to a total of 40 workers that directly involved in 
the receiving process. This Value-Added Assessment (VAA) is used to determine the type of waste in the receiving process that divided into Value Added (VA), NonValue Added (NVA), or Necessary Non-value Added (NNVA).

Table 1 Value Added Assessment (VAA) Result

\begin{tabular}{|c|c|c|c|c|c|c|}
\hline \multirow[t]{2}{*}{ NO } & \multirow{2}{*}{ Actor } & \multirow{2}{*}{ Location } & \multirow[t]{2}{*}{ Activities } & \multicolumn{3}{|c|}{$\begin{array}{c}\text { Type of } \\
\text { Activities }\end{array}$} \\
\hline & & & & VA & NVA & NNVA \\
\hline \multirow{4}{*}{1.} & \multirow{4}{*}{$\begin{array}{l}\text { Planning \& } \\
\text { Control }\end{array}$} & \multirow{4}{*}{$\begin{array}{l}\text { Planning } \\
\text { \& Control }\end{array}$} & User submit open stack requests & $\mathrm{x}$ & & \\
\hline & & & $\begin{array}{l}\text { Officer receive open stack request from } \\
\text { customer and make vessel voyage and } \\
\text { open stack details }\end{array}$ & $\mathrm{X}$ & & \\
\hline & & & $\begin{array}{l}\text { Planning control officer confirm stack } \\
\text { approval on open booking }\end{array}$ & $\mathrm{X}$ & & \\
\hline & & & $\begin{array}{l}\text { Officer give open stack request } \\
\text { confirmation to customers. }\end{array}$ & $\mathrm{x}$ & & \\
\hline \multirow{6}{*}{2.} & \multirow{6}{*}{$\begin{array}{l}\text { Billing \& } \\
\text { Financial } \\
\text { Officer }\end{array}$} & \multirow{6}{*}{$\begin{array}{l}\text { Billing \& } \\
\text { Financial }\end{array}$} & $\begin{array}{l}\text { Users attach PEB documents, NPE, } \\
\text { Booking Confirmation letter from } \\
\text { voyage to front liner officers (CSO). }\end{array}$ & $\mathrm{x}$ & & \\
\hline & & & $\begin{array}{l}\text { Front liner officer (CSO) verify user's } \\
\text { documents, if it's not suitable, it will be } \\
\text { returned and if the documents is correct } \\
\text { it will be submitted to the Back-Office } \\
\text { Officer and user will get a queue } \\
\text { number. }\end{array}$ & $\mathrm{X}$ & & \\
\hline & & & $\begin{array}{l}\text { User will wait until finance officer call } \\
\text { their queue number }\end{array}$ & & $\mathrm{X}$ & \\
\hline & & & $\begin{array}{l}\text { Back office officers receive documents } \\
\text { from front liner to process request on } \\
\text { new billing system (NBS). }\end{array}$ & $\mathrm{x}$ & & \\
\hline & & & $\begin{array}{l}\text { Finance Officer receives Proforma / } \\
\text { Prenote from the Billing officer (Back } \\
\text { Office) }\end{array}$ & & $\mathrm{X}$ & \\
\hline & & & $\begin{array}{l}\text { Finance Officer calls user by their } \\
\text { queue number for payment via EDC }\end{array}$ & & $\mathrm{x}$ & \\
\hline \multicolumn{4}{|c|}{ User will wait again until front liner officer called } & & $\mathrm{x}$ & \\
\hline \multirow[t]{4}{*}{3.} & \multirow[t]{2}{*}{ Billing Officer } & \multirow[t]{2}{*}{ Billing } & $\begin{array}{l}\text { Officer issues an Invoice after payment } \\
\text { and changes the payment status } \\
\text { information }\end{array}$ & $\mathrm{x}$ & & \\
\hline & & & Back office officer issues receiving card & $\mathrm{x}$ & & \\
\hline & & & $\begin{array}{l}\text { Back office officer files the output } \\
\text { (Invoice, receiving card, and supported } \\
\text { documents) in one file based on the } \\
\text { vessel, voyage, ETA. }\end{array}$ & $\mathrm{x}$ & & \\
\hline & & & $\begin{array}{l}\text { Back office officer hand over SP2 card } \\
\text { to the front liner officer. }\end{array}$ & $\mathrm{X}$ & & \\
\hline \multicolumn{4}{|c|}{$\begin{array}{l}\text { Front liner calls user based on queue number and hand over receiving card } \\
\text { to users. }\end{array}$} & & & $\mathrm{x}$ \\
\hline \multicolumn{4}{|c|}{ Trucks waiting on gate in for inspection } & & $\mathrm{x}$ & \\
\hline
\end{tabular}




\begin{tabular}{|c|c|c|c|c|c|c|}
\hline \multirow[t]{2}{*}{ NO } & \multirow{2}{*}{ Actor } & \multirow{2}{*}{ Location } & \multirow{2}{*}{ Activities } & \multicolumn{3}{|c|}{$\begin{array}{c}\text { Type of } \\
\text { Activities }\end{array}$} \\
\hline & & & & VA & NVA & NNVA \\
\hline \multirow{7}{*}{4.} & \multirow{7}{*}{$\begin{array}{l}\text { Control Tower } \\
\& \text { Gate } \\
\text { Inspector } \\
\text { Officer }\end{array}$} & \multirow{7}{*}{ Gate In } & $\begin{array}{l}\text { Container trucks follows inspection } \\
\text { procedure on gate in receiving }\end{array}$ & $\mathrm{x}$ & & \\
\hline & & & $\begin{array}{l}\text { Gate inspector checks the container on } \\
\text { gate in }\end{array}$ & $\mathrm{x}$ & & \\
\hline & & & $\begin{array}{l}\text { Gate in operator files the results of } \\
\text { inspection }\end{array}$ & $\mathrm{x}$ & & \\
\hline & & & $\begin{array}{l}\text { Gate in operator input container seals } \\
\text { data to the system }\end{array}$ & $\mathrm{x}$ & & \\
\hline & & & $\begin{array}{l}\text { Gate in operator input container type } \\
\text { chassis data to the system }\end{array}$ & $\mathrm{x}$ & & \\
\hline & & & Weighing & & & \\
\hline & & & $\begin{array}{l}\text { Gate in operator print slip / job slip } \\
\text { (CMS) }\end{array}$ & & & \\
\hline \multicolumn{4}{|c|}{ Trucks go to the container yard. } & & & $\mathrm{x}$ \\
\hline \multicolumn{4}{|c|}{ Trucks waiting for yard officer for CMS Checking } & & $\mathrm{x}$ & \\
\hline \multirow{4}{*}{5.} & \multirow{4}{*}{$\begin{array}{l}\text { Control Tower } \\
\& \text { Yard } \\
\text { Operational } \\
\text { Officer }\end{array}$} & \multirow{4}{*}{ Yard } & CMS Checking & & $\mathrm{x}$ & \\
\hline & & & $\begin{array}{l}\text { Yard officers moves container from } \\
\text { truck to stacking yard (Lift OFF) }\end{array}$ & $\mathrm{x}$ & & \\
\hline & & & $\begin{array}{l}\text { Container placement data by yard } \\
\text { officer }\end{array}$ & $\mathrm{x}$ & & \\
\hline & & & $\begin{array}{l}\text { Equipment Interchange Receipt (EIR) } \\
\text { damage data by yard officer }\end{array}$ & $\mathrm{x}$ & & \\
\hline \multicolumn{4}{|c|}{ Trucks go to the gate out } & & & $\mathrm{x}$ \\
\hline \multirow{4}{*}{6.} & \multirow{4}{*}{$\begin{array}{l}\text { Control Tower } \\
\& \text { Gate Officer }\end{array}$} & \multirow{4}{*}{ Gate Out } & $\begin{array}{l}\text { Gate out officer input gate in and gate } \\
\text { out data to the system }\end{array}$ & $\mathrm{x}$ & & \\
\hline & & & $\begin{array}{l}\text { Gate out officer input truck's duration } \\
\text { at terminal during Truck Round Time } \\
\text { (TRT) process to the system }\end{array}$ & & $\mathrm{x}$ & \\
\hline & & & $\begin{array}{l}\text { Gate out officer input data for gate } \\
\text { movement report }\end{array}$ & & $\mathrm{x}$ & \\
\hline & & & Gate out officer take the receiving card & $\mathrm{x}$ & & \\
\hline
\end{tabular}

The results of the questionnaire show that there is a total of nine non-value activities consist of twenty-five value added activities, nine Non-Value Added (NVA) activities and three Necessary but Non-Value Added (NNVA) activities. Those non-value-added activities are wastes and thus, should be eliminated. An analysis is performed to relate those non-value activities using the seven-waste category. The results of the Value-Added Assessment (VAA) are taken descriptively.

There are 3 types of waste of Non-Value-Added Activities that categorized as waiting, transportation, and motion.

The results obtained that there are 5 activities in waiting, 2 activities in transportation waste and 5 activities included in motion waste. Waste can cause inefficiency in the process of receiving activities, the waste must be eliminated in order to increase service and customer satisfaction. 
Table 2 Waste Analysis Result

\begin{tabular}{|c|c|c|}
\hline No & $\begin{array}{l}\text { Type of } \\
\text { Waste }\end{array}$ & Activity \\
\hline \multirow{5}{*}{1.} & \multirow{5}{*}{ Waiting } & User will wait until finance officer call their queue number \\
\hline & & $\begin{array}{l}\text { Finance Officer receives Proforma / Prenote from the Billing officer (Back } \\
\text { Office) }\end{array}$ \\
\hline & & User will wait again until front liner officer called \\
\hline & & Trucks waiting on gate in for inspection \\
\hline & & Trucks waiting for yard officer for CMS Checking \\
\hline \multirow{2}{*}{2.} & \multirow{2}{*}{ Transportation } & Trucks go to the container yard. \\
\hline & & Trucks go to the gate out \\
\hline \multirow{5}{*}{ 3. I } & \multirow{5}{*}{ Motion } & $\begin{array}{l}\text { Front liner calls user based on queue number and hand over receiving card } \\
\text { to users. }\end{array}$ \\
\hline & & CMS Checking \\
\hline & & Finance Officer calls user by their queue number for payment via EDC \\
\hline & & $\begin{array}{l}\text { Gate out officer input truck's duration at terminal during Truck Round } \\
\text { Time (TRT) process to the system }\end{array}$ \\
\hline & & Gate out officer input data for gate movement report \\
\hline
\end{tabular}

\section{Conclusions}

In the process of receiving PT IPC Terminal Container there are still processes of activities that do not add value (NVA), where in lean operations activities that does not add value in the eyes of the customer is a waste. In the receiving process, there are 3 activities that are necessary but Non-added value (NNVA) and there are 9 activities that non-add value (NVA) identified in the receiving process.

- 3 Necessary Non-Value Added (NNVA) activities:

- Submission of receiving card

- Container trucks go to the stacking field

- Container to gate out

- 9 Non-Value Added (NVA) activities:

- The service user is waiting to be called by an officer.

- Finance officers receive proforma.

- Financial officers call service users to make payments via EDC.

- The service user will wait to be called back by the front liner clerk.

- Container trucks queue at the gate in for inspection.

- The container truck is waiting for the field officer to check the CMS.

- The officer checks the CMS. 
- Officers collect data on the duration of trucks at the terminal in the receiving process for the TRT report.

- Officers make data collection for the gate movement report.

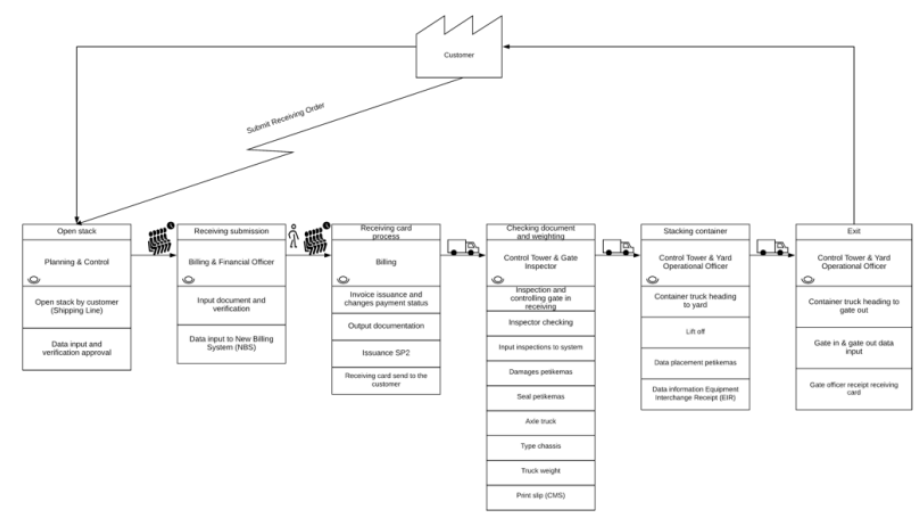

Figure 3 Proposed Value Stream Mapping (VSM)

Proposed mapping is illustrated above as recommendation for the company. According to the results, PT IPC Container terminal need to eliminate 9 process of non-value-added activities and the process of Necessary Non-Value-Added activity needs an automation so that the receiving process could be more effective and efficient. The priority improvements suggested are having all of administration in billing service by system, adding QR code for Container Moving Slip (CMS) to minimize the cycle time, Using Optical Character Recognition (OCR) on gate in. It is hoped the Tanjung Priok port can continuously improve their performance to be more efficient and effective port in Indonesia.

\section{References}

1. Amrina, E., Kamil, I., \& Rahmad, D. (2019). Waste assessment using a lean approach in receiving process of container terminal: A case of Teluk Bayur Port. IOP Conference Series: Materials Science and Engineering, 602(1), 1-8. https://doi.org/10.1088/1757-899X/602/1/012050

2. Andrés-López, E., González-Requena, I., \& Sanz-Lobera, A. (2015). Lean Service: Reassessment of Lean Manufacturing for Service Activities. Procedia Engineering, 132, 23-30. https://doi.org/10.1016/j.proeng.2015.12.463

3. Asnan, R., Nordin, N., \& Othman, S. N. (2015). Managing Change on Lean Implementation in Service Sector. Procedia - Social and Behavioral Sciences, 211, 313-319. https://doi.org/10.1016/j.sbspro.2015.11.040

4. Daruka, P., Agarwal, T., \& Sharma, D. V. (2016). Lean Implementation on Indian Manufacturing Firm. International Journal of Research and Engineering, 03(12), 21-26. 
5. Dat Minh, N., Danh Nguyen, N., \& Kien Cuong, P. (2018). Applying Lean Tools and Principles to Improve Sustainability of Waste Management: A Case Study. Journal of Industrial and Manufacturing Industry, 1, 1-16. https://doi.org/10.20944/preprints201806.0214.v1

6. Froon, B. (2010). Implementing Lean Management Globally. Tilburg University.

7. Gupta, S., \& Sharma, M. (2018). Empirical analysis of existing lean service frameworks in a developing economy. International Journal of Lean Six Sigma, 9(4), 482-505. https://doi.org/10.1108/IJLSS-03-2016-0013

8. Gupta, S., Sharma, M., \& Sunder M, V. (2016). Lean Services: A Systematic Review. International Journal of Productivity and Performance Management, 65(8), 1025-1056. https://doi.org/10.1108/IJPPM-02-2015-0032

9. Heizer, J., Render, B., \& Munson, C. (2017). Operations Management; Sustainability and Supply Chain Management (twelfth). Pearson.

10. Hines, P., \& Rich, N. (1997). The Seven Value Stream Mapping Tools. International Journal of Operations \& Production Management, 17(1), 46-64.

11. Hines, P., \& Taylor, D. (2000). Going lean. In Lean Enterprise Research Centre.

12. Morlock, F., \& Meier, H. (2015). Service Value Stream Mapping in Industrial Product-Service System Performance Management. Procedia CIRP, 30, 457461. https://doi.org/10.1016/j.procir.2015.02.128

13. MUC Consultant Group. (2019). Laporan Survei Pelanggan PT IPC Terminal Petikemas Tahun 2019.

14. Nagapan, S., Rahman, I. A., Azis, A. A. A., Memon, A. H., \& Zin, R. M. (2012). Identifying Causes of Construction Waste - Case of Central Region of Peninsula Malaysia. International Journal of Integrated Engineering, Issue on Civil and Environmental Engineering, 4(2), 22-28.

15. Ohno, T. (1988). Toyota Production System: Beyond Large-Scale Production.

16. Olesen, P., Powell, D., Hvolby, H.-H., \& Fraser, K. (2015). Using lean principles to drive operational improvements in intermodal container facilities a conceptual framework. Journal of Facilities Management Using, 13(03), 266281.

17. PT IPC Terminal Petikemas. (2018). PT IPC Terminal Petikemas Annual Report 2018.

18. Radnor, Z. J., Walley, P., Stephens, A., \& Bucci, G. (2006). Evaluation of the Lean Approach to Business Management and Its Use in the Public Sector. In Radnor, Zoe. www.scotland.gov.uk/socialresearch

19. Rother, M., \& Shook, J. (1999). Learning to See: Value Stream Mapping to Add Value and Eliminate Muda. In Lean Enterprise Institute Brookline. www.lean.org

20. Sanker, E. A. (2020). What Are Lean Services? Wise Geek. https://www.wisegeek.com/what-are-lean-services.htm

21. Santosa, W. A., \& Sugarindra, M. (2018). Implementation of lean manufacturing to reduce waste in production line with value stream mapping approach and Kaizen in division sanding upright piano, case study in: PT. X. MATEC Web of Conferences, 154, 1-4. https://doi.org/10.1051/matecconf/201815401095 
22. Seth, D., \& Gupta, V. (2005). Application of value stream mapping for lean operations and cycle time reduction: An Indian case study. Production Planning and Control, 16(1), 44-59. https://doi.org/10.1080/09537280512331325281

23. Seth, D., Seth, N., \& Goel, D. (2008). Application of value stream mapping (VSM) for minimization of wastes in the processing side of supply chain of cottonseed oil industry in Indian context. Journal of Manufacturing Technology Management, 19(4), 529-550. https://doi.org/10.1108/17410380810869950

24. Sharma, S. L., Mudgal, P., Jha, A. K., Kumar, A., \& Singh, G. K. (2018). Study of Lean Manufacturing for Manufacturing of Auto Components.

25. Subramaniam, S., Abdullah, A. H. Bin, Nagapan, S., Kupusamy, K., Manian, H., \& Daud, Z. (2018). Investigate how construction waste generation rate is different for every types of project in Peninsular Malaysia using site visit method. International Journal of Integrated Engineering, 10(1), 150-156. https://doi.org/10.30880/ijie.2018.10.01.022

26. Torres, A. S., \& Gati, A. M. (2009). Environmental value stream mapping (EVSM) as sustainability management tool. PICMET: Portland International Center for Management of Engineering and Technology, Proceedings, 16891698. https://doi.org/10.1109/PICMET.2009.5261967

27. Vignesh, V., Suresh, M., \& Aramvalar than, S. (2016). Lean in Service Industries: A Literature Review. IOP Conference Series: Materials Science and Engineering, 149(1), 1-10. https://doi.org/10.1088/1757-899X/149/1/012008

28. Waterman, J., \& McCue, C. (2012). Lean Thinking Within Public Sector Purchasing Department: The Case of the U.K Public Service. Journal of Public Procurement, 12(4), 505-527.

29. Womack, J. P., Jones, D. T., \& Roos, D. (1990). The Machine That Changed the World Rawson Associates, New York, NY. Free Press.

\section{About Our Authors}

Mohammad Ichsan is an Assistant Professor in Binus Business School of Bina Nusantara University (AACSB accredited). He has pursued his DiplomIngenieur in Electrical Engineering from Hochschule Darmstadt, Germany prior to get his master's degree in project management from the University of Indonesia. Dr. Ichsan has continued his study and received his doctoral degree in Strategic Management. His teaching area is project management and operations management, meanwhile his research domain is project portfolio management, project management office practices and project risk management.

Bestari Nur Arasy, Mohammad Fadly, Muhamad RizkiNafi Adhani are students from Binus Business School Undergraduate Program, Management Program. They are completing their bachelor's degree in Management in area of Quality Management. Their thesis is supervised by Dr. Mohammad Ichsan. 